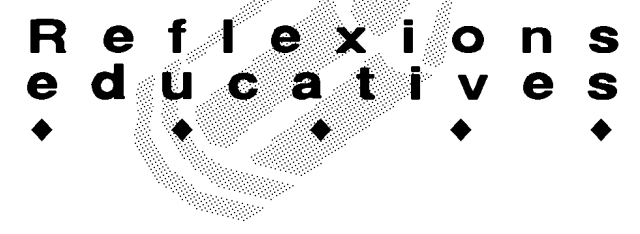

\title{
LA COMUNICACIÓ A LA DIDÀCTICA DE LES CIÈNCIES SOCIALS
}

\author{
Isabel Ramírez Romero. Mestra del CEIP Cesc Aldea. Terrassa. \\ Antoni Santisteban Fernández. Didàctica de les Ciències Socials. URV
}

\begin{abstract}
"El reconeixement per part de cadascú que l'altre és; que és una persona, que té un valor, que sap -almenys en part- el que es fa, que té una intuïció del que vol..." [Carl Rogers. El proceso de convertirse en persona. pàg.42].

L'ensenyament i l'aprenentatge són parts del procés comunicatiu que es dóna a l'aula. L'educació és comunicació. El concepte de metodologia o d'estratègies per ensenyar i aprendre no és res més que formes de comunicació, ja sigui a partir dels materials curriculars 0 de l'organització de l'aula o de l'escola, dels espais o dels horaris. Les característiques del mestre com a comunicador són decisives en l'èxit 0 el fracàs d'un determinat mètode o model educatiu.

La motivació com a factor aïllat, canalitzada a través de materials $o$ de determinats recursos més o menys originals, és un esforç poc productiu si no es genera dins d'un entorn de comunicació adequat. S'ha d'acceptar que el bon o la bona comunicadora no ha de recórrer a complicades estratègies de motivació, perquè es fa escoltar, perquè sap quan ha de deixar parlar els nens $i$ nenes. Perquè comprèn amb agilitat la manera d'aprendre que té cada alumne.

Quasi bé podríem parlar d'un codi individual de cada persona. El professorat bon comunicador esbrina aquest codi i el fa comú per facilitar les condicions d'aprenentatge individual. Aquest procés genera, al mateix temps, una millor comunicació amb el grupclasse, que té també un codi col-lectiu de funcionament i per als intercanvis. Entenem, en aquest cas, per codi el conjunt d'elements compartits d'experiències i coneixements, un llenguatge compost per elements lingüístics i elements contextuals compartits a l'aula (EDWARDS i MERCER, 1987).

L'entorn comunicatiu és especialment important a l'ensenyament de les ciències socials, ja que l'aula s'ha de convertir en un laboratori on s'han de reproduir les interaccions socials, la participació democràtica, i on s'han d'aprendre les habilitats comunicatives i el pensament crític, on s'ha de preparar per a la intervenció social. La comunicació que s'estableixi serà l'eix vertebrador per als aprenentatges socials i serà per ella
\end{abstract}

mateixa l'aprenentatge més important dels futurs ciutadans i ciutadanes.

Com es pot observar al nostre mapa conceptual, les ciències socials es poden definir i organitzar a partir d'uns conceptes clau, tal com proposen diversos autors. Els conceptes clau, des de la concepció crítica, són considerats de gran utilitat per a la selecció i seqüenciació dels continguts, i en general prioritzen els conceptes: organització, relacions socials, temps (canvi) i espai. Des del nostre punt de vista aquests conceptes giren al voltant de la idea de comunicació des de dues vessants. En primer lloc, com a concepte social que té unes característiques determinades al nostre medi o segons a la realitat que s'aplica (família, escola, barri, poble, ciutat...), i que s'ha de construir al llarg de l'escolaritat de l'alumnat. I, en segon terme, com a instrument, com a forma d'entendre el procés d'ensenyament i aprenentatge, la bona comunicació o l'ambient comunicatiu que es genera a l'aula fruït de la feina del professorat, com a facilitador dels aprenentatges o com a generador de diàleg, debat, conflictes, etc.

Seguint el nostre esquema en forma de mapa conceptual, la comunicació des de les ciències socials és interrelació, ja que la societat té sentit com a medi d'interaccions personals o grupals. És interdependència, ja que la comunicació democràtica genera vincles de dependència en els actes de les persones, que afecten altres persones del mateix entorn. És, segons les seves característiques, segons el model i segons la intencionalitat d'emissor i receptor, de qui comparteix la informació o la formació, socialització -integració social o cultural-, o contrasocialització -qüestionament crític o transformació o canvi de la mateixa societat o cultura. Potser hem de parlar de deconstrucció, és a dir, formar el pensament crític no és destruir les concepcions socials de l'alumnat, sinó qüestionar-les, desmuntar-les, posarles en conflicte per a l'alumnat, amb l'objectiu de reconstruir-les.

El mapa conceptual que presentem desenvolupa aquesta argumentació, que vol trobar aquestes relacions entre la comunicació i l'aprenentatge social. 

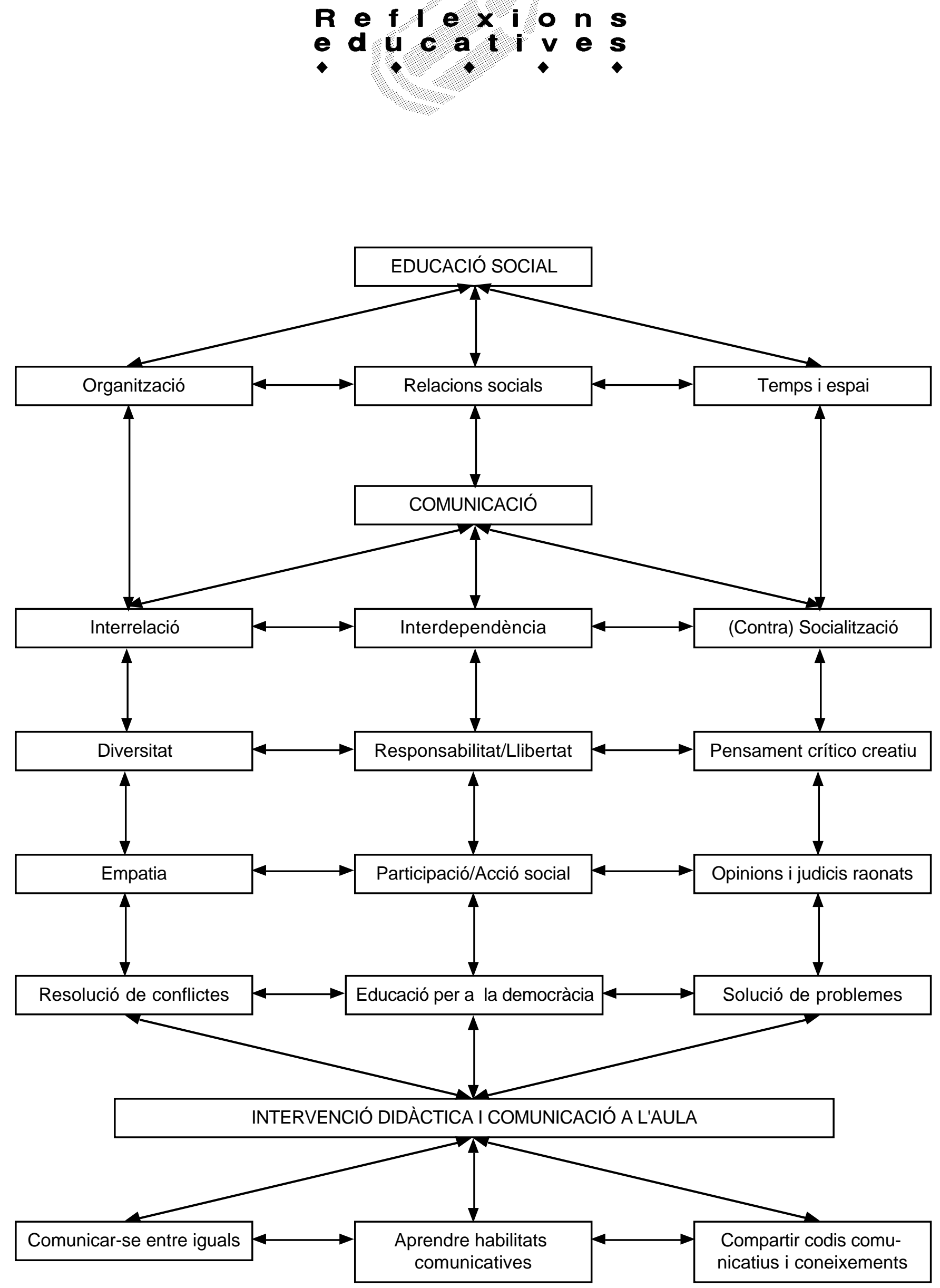


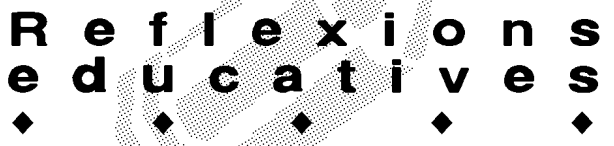

\section{Interrelació}

La interrelació és un concepte clau que es construeix tota la vida a partir de les nostres experiències. Els nostres esquemes de coneixement s'amplien i es fan més complexos a partir dels aprenentatges socials i de les vivències personals. En aquest sentit la comunicació és l'essència de les relacions socials, en els seus diferents formats o àmbits. L'aula ha de ser el marc on es puguin experimentar una gran diversitat de relacions interpersonals (CAMPS, 1998). La interrelació s'ha de basar en l'existència de la diversitat de persones a l'aula i a la societat en general. De la mateixa manera, aquesta diversitat s'ha d'entendre des de l'aprenentatge de les capacitats per a l'empatia, ja que aquesta és un element generador de comunicació. Interrelació, diversitat i empatia són conceptes previs, significatius dins de l'aprenentatge de les ciències socials per a la resolució de conflictes.

Som capaços de resoldre les confrontacions personals o grupals quan som conscients de la diversitat de tot tipus dins la democràcia, quan utilitzem les habilitats necessàries per posar-nos en el lloc dels altres, quan acceptem que els conflictes se solucionen a partir del diàleg i del debat, del respecte i del consens; en definitiva, d'un tipus de comunicació que afavoreixi l'acord, la cooperació, la solidaritat i, sobretot, que expressi de manera sincera i autèntica les pròpies conviccions, i, sens dubte, les possibilitats de renúncia de les pretensions de l'individu o del grup. Aquest fet és general dins la idea de societat concretada en qualsevol entorn, així com a l'aula, on alumnes i mestres han d'experimentar totes aquestes interrelacions, existeix "necesidad de recrear los programas de educación en valores en la realidad y contexto específico y singular de la comunidad escolar. No sólo en lo referente al contexto sociocultural y económico en el que la escuela está ubicada, sino también en el propio microcosmos, en la atmósfera moral de la institución escolar. Las posibilidades de la escuela en relación con la familia y los medios de comunicación son ciertas, aunque no siempre son asumidas de forma esperanzada e ilusionada por el profesorado. Pero sobre todo el papel de la escuela y la función del profesorado como regulador de las interacciones entre iguales, a veces no tan iguales, es fundamental y quizás una de las funciones más genuinas de la escuela. Asumir la función de mediador de conflictos, de regulador de interacciones en el seno del grupo de iguales y en la dinámica de la vida cotidiana en la escuela es fundamental." (MARTíNEZ, 1998).

\section{Interdependència}

La comunicació implica també interdependència, és a dir, aprendre que les nostres accions tenen conseqüències en les persones que estan al nostre voltant; per tant, exercir la nostra llibertat d'expressió i d'actuació ha d'anar acompanyat del sentit de la responsabilitat

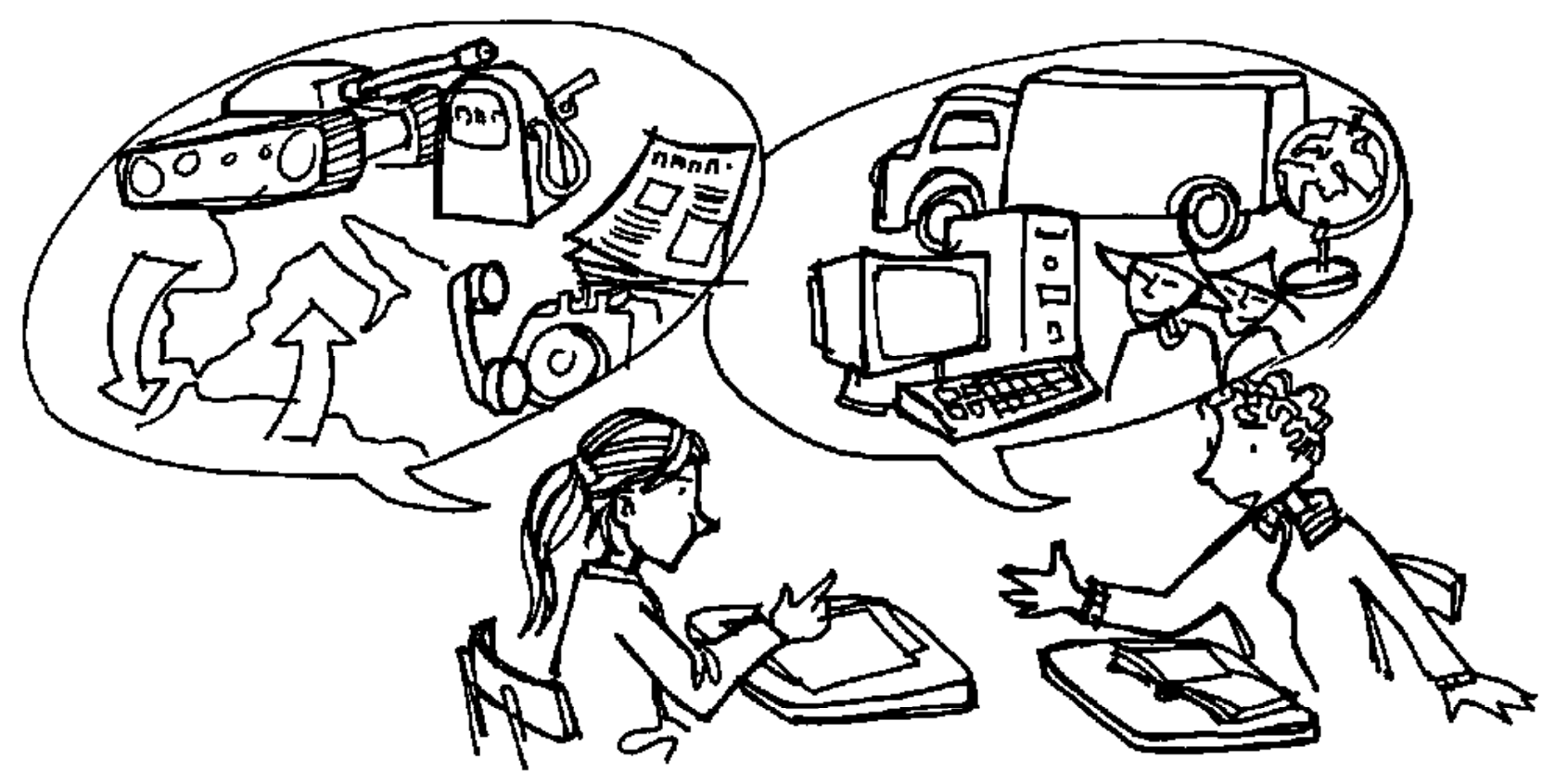




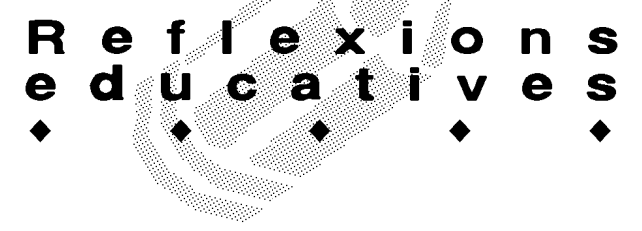

(ARENDT, 1997). Llibertat i responsabilitat són dos conceptes, a la vegada, interdependents. Ensenyem ciències socials, com a finalitat última, per educar una ciutadania participativa i que intervingui en la societat per canviar-la i millorar-la.

Si considerem la democràcia com un sistema d'organització en construcció, com una mena d'utopia realitzable, un camí que s'ha de recórrer cada dia (TOURAINE, 1994), llavors la comunicació és l'instrument essencial per ensenyar o per aprendre els valors democràtics (SANTISTEBAN, 1999). Hem de considerar que existeix sempre un tipus de comunicació òptima a la qual hem de tendir o ens hem d'aproximar, dins l'aula.

La comprensió de la interdependència en les relacions socials i en la comunicació és la comprensió de la solidaritat, sense la qual no hi ha democràcia. La participació responsable en el debat i en l'acció dóna la mesura de l'autèntica llibertat. Ens comuniquem perquè volem escoltar, intercanviar, aprendre, perquè tenim idees 0 conviccions que estem disposats a defensar, però restem sempre oberts a considerar les idees i les conviccions dels altres.

La comunicació sense el concepte d'interdependència és una comunicació unilateral, una expressió radical de concepcions inalterables, que donen lloc al fanatisme, a l'immobilisme i que no enriqueixen la democràcia, sinó que deterioren els seus fonaments.

\section{(Contra) Socialització}

La socialització es dóna en un temps i en un espai determinats, però l'escola no es pot limitar a socialitzar, també ha d'ensenyar a qüestionar la mateixa cultura i el medi social on vivim (PÉREZ GÓMEZ, 1998). Aquesta idea, que es pot anomenar contrasocialització (GÓMEZ RODRÍGUEZ, 1998), no significa el rebuig a les tradicions, la cultura o la identitat, sinó que vol dir educar el pensament crítico-creatiu, per poder descriure el funcionament de la societat, per millorar-la, pensant alternatives de canvi social.

Un aspecte essencial de la comunicació social és crear les condicions necessàries o idònies perquè l'alumnat pugui construir les seves opinions i emetre judicis raonats i raonables. Això significa ensenyar les ciències socials a partir de problemes socials, propers a l'alumnat o donar la paraula en un debat adequat sobre qüestions problemàtiques del medi social on viuen.

La finalitat d'un ambient comunicatiu adequat a l'aula és donar la possibilitat a l'alumnat d'exercir un pensament reflexiu, és aconseguir que l'alumnat sigui capaç d'imaginar solucions als problemes socials, unes vegades molt propers, d'altres presents als mitjans de comunicació o que afecten altres col.lectius. El paper del professorat és que aquests problemes siguin presents a l'aula, al currículum: Per on ha de passar la carretera? Per què és tan cara l'autopista? Per què ha pujat la benzina? Per què hem deixat de menjar vedella? Per què es queixen els pagesos? Per què les persones que surten als anuncis són així? Per què als anuncis de detergents sempre surten dones?

Per solucionar problemes hem de partir de l'autoconeixement i de l'autoestima de l'alumnat, del coneixement de la seva pertinença a grups socials, naturals 0 associacions voluntàries, on desenvolupa les seves activitats, les seves afeccions. Dins el grup la persona estableix diferents formes de comunicació que donen lloc a l'establiment de jerarquies, de concepcions del poder, de la democràcia, del repartiment de rols o de responsabilitats. El grup dóna la mesura de les possibilitats personals de desenvolupament. Treballar la comunicació vol dir ajudar l'alumnat a situar-se al seu medi social, dins els seus grups; en definitiva, a localitzarse socialment al món. Els nens i nenes són membres de la societat amb drets $\mathrm{i}$ deures, formen part de la ciutadania, són consumidors, usuaris de serveis (FIEN, 1993), actors de la història del present.

\section{Intervenció didàctica i comunicació a l'aula}

Un dels elements fonamentals que s'han de treballar a l'ensenyament de les ciències socials és la comunicació entre iguals, l'aprenentatge del treball cooperatiu. És important diversificar les interaccions entre l'alumnat per ampliar i millorar els seus esquemes de coneixement sobre la societat, les seves capacitats de participació.

El professorat ha de ser comprensiu, autèntic, elaborador de conflictes, creatiu i compromès, un bon comunicador (MARTíN, 1991). Ha d'exercir la neutralitat activa, com a actitud fonamental per al foment del diàleg i del debat, per al sorgiment de preguntes que generen reflexió i provoquen d'altres preguntes. Els nens i nenes són filòsofs per natura, ja que sempre es pregunten el perquè dels comportaments $i$ actituds de les persones 0 dels grups socials (LIPMAN, 1991). La funció del professorat és deixar florir la comunicació, cultivar-la, generant dubtes, aclarint conceptes, animant a noves preguntes.

Des d'un enfocament crític el discurs del mestre sempre ha de ser argumentatiu, superant presentacions 0 informacions descriptives o explicatives. Al mateix temps, també s'ha d'ensenyar l'alumnat a argumentar, en la resolució de conflictes, en la participació democràtica, en la solució de problemes.

L'aprenentatge de les habilitats comunicatives 


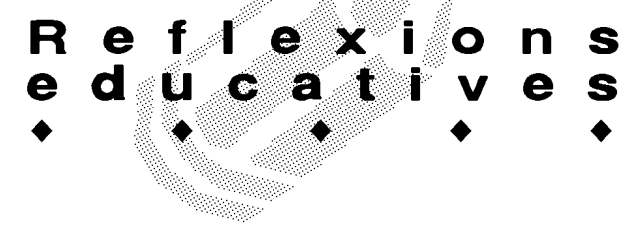

(PORTILLO, 1991) és, doncs, un aspecte essencial del treball a l'aula en ciències socials. La seva màxima expressió és l'argumentació, tant en la funció del professorat com en l'aprenentatge de l'alumnat. Les habilitats socials inclouen les habilitats comunicatives. Comunicar-se és relacionar-se, és viure, és sentir-se part de la societat, element actiu, dins l'aula o en la vida quotidiana. L'escola $i$, en concret, l'àrea de ciències socials, ha de ser un marc propici per a aquests aprenentatges de la comunicació i de les relacions humanes.

Què és comunicar-se? La comunicació que comporta aprenentatge implica compartir codis d'intercanvi d'informació, de tal manera que s'arribin a compartir també coneixements. L'educació social demana del mestre que sigui un gestor del coneixement, que faciliti aprendre a aprendre, que doni la possibilitat a l'alumnat de deconstruir i reconstruir els seus sabers: "Ser un buen gestor del conocimiento no es un atributo de personas que sólo 'saben', sino de personas que sobre todo saben cómo aprender y cómo enseñar a que otros aprendan a aprender" (MARTíNEZ, 1998). A més a més de gestor del coneixement, el professorat ha de gestionar també la comunicació a l'aula.

Les idees que hem exposat són una incitació al canvi, tant en la formació del professorat com en els hàbits diaris del treball dels mestres. Aquesta pretensió, és una utopia? La comunicació, com a conjunt de coneixements ben definits, forma part del currículum de publicistes i de la formació en les multinacionals més avançades. Aquestes proclamen la cooperació, l'adaptació al canvi, l'anàlisi crítica de les relacions de treball, la recerca de la productivitat que té cura de l'actor, l'obtenció de beneficis des de l'autocomplaença dels treballadors i treballadores... La comunicació, amb aquest plantejament, també hauria de formar part del currículum en la formació del professorat, de l'ambient de l'aula universitària, i a l'escola. Es tractaria d'aprendre a "comunicar" de forma afectiva i efectiva. El professorat ha d'estar preparat per transmetre aquestes habilitats comunicatives sense les quals el coneixement esdevé inútil. El treball de les ciències socials a l'aula ha de passar de forma ineludible per aquest plantejament. No estem, com molts proclamen, en la societat de l'aprenentatge, amb les noves tecnologies i la comunicació fascinant. Estem a la societat de la informació, aclaparadora. Cal reivindicar de nou el pensament reflexiu de Dewey enfront de la societat de l'espectacle i la parafernàlia. La comunicació.

\section{Referències bibliogràfiques}

ARENDT, H. ¿Qué es la política? Edit. Paidós/ICE de la UAB. Barcelona. 1997.

CAMPS, V. La escuela ante el reto del saber práctico. «Infancia y Aprendizaje», 82 (1998) 65-73.

EDWARDS, D. i MERCER, N. El conocimiento compartido. El desarrollo de la comprensión en el aula. Edit. Paidós/MEC. Madrid. 1987.

FIEN, J. Geografía, sociedad y vida cotidiana. «Documents d'Anàlisi Geogràfica», 21 (1993) 73-90.

GÓMEZ RODRÍGUEZ, E. La Didáctica de las Ciencias Sociales y su compromiso en la formación de los valores democráticos, en VVAA. La formación del profesorado y la didáctica de las ciencias sociales. Ed. de la Universitat de Lleida. 1998. Pàgs. 37-55.

LIPMAN, M., SHARP, A.M.i OSCANYAN, F.S. Filosofia a l'escola. Edit. Eumo/IREF. Barcelona. 1991.

MARTín, X. Actituds de l'educador per una escola dialógica. «Perspectiva Escolar», 157 (setembre 1991) 25-29.

MARTíNEZ, M. Educación en valores: un ámbito necesario en la formación del profesorado. «Infancia y Aprendizaje», 82. (1998) 91-97.

PÉREZ GÓMEZ, A. La cultura escolar en la sociedad neoliberal. Edit. Morata. Madrid. 1998.

PORTILLO, M.C. Habilidades comunicativas. MARTíNEZ, M.; PUIG, J. M. (coord.). La educación moral. Perspectivas de futuro y técnicas de trabajo. Edit. Graó/ICE de la UB. Barcelona. 1991. Pàgs. 93-103.

SANTISTEBAN, A. Educació política: per què, què icom? Quan dos per dos no són quatre. «Perspectiva Escolar», 234 (1999) 19-30.

TOURAINE, A. ¿Qué es la democracia? Edit. Temas de Hoy. Madrid. 1994. 